Economic Integration in Asia and India 
Other books by IDE-JETRO

INDUSTRIAL CLUSTERS IN ASIA

Akifumi Kuchiki and Masatsugu Tsuji (editors)

SPATIAL STRUCTURE AND REGIONAL DEVELOPMENT IN CHINA

Nobuhiro Okamoto and Takeo Ihara (editors)

GENDER AND DEVELOPMENT

The Japanese Experience in Comparative Perspective

Mayumi Murayama (editor)

EAST ASIA'S DE FACTO ECONOMIC INTEGRATION

Daisuke Hiratsuka (editor)

RECOVERING FINANCIAL SYSTEMS

China and Asian Transition Economies

Mariko Watanabe (editor)

DEVELOPMENT OF ENVIRONMENTAL POLICY IN JAPAN AND ASIAN

COUNTRIES

Tadayashi Terao and Kenji Otsuka (editors)

REGIONAL INTEGRATION IN EAST ASIA

From the Viewpoint of Spatial Economics

Masahisa Fujita (editor)

NEW DEVELOPMENTS OF THE EXCHANGE RATE REGIMES IN

DEVELOPING COUNTRIES

Hisayuki Mitsuo (editor) 


\section{Economic Integration in Asia and India}

Edited by

Masahisa Fujita 


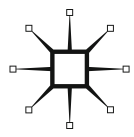

(c) Institute of Developing Economics (IDE), JETRO 2008

Softcover reprint of the hardcover 1st edition 2008 978-0-230-52085-1

All rights reserved. No reproduction, copy or transmission of this publication may be made without written permission.

No paragraph of this publication may be reproduced, copied or transmitted save with written permission or in accordance with the provisions of the Copyright, Designs and Patents Act 1988, or under the terms of any licence permitting limited copying issued by the Copyright Licensing Agency, 90 Tottenham Court Road, London W1T 4LP.

Any person who does any unauthorized act in relation to this publication may be liable to criminal prosecution and civil claims for damages.

The authors have asserted their rights to be identified as the authors of this work in accordance with the Copyright, Designs and Patents Act 1988.

First published 2008 by

PALGRAVE MACMILLAN

Houndmills, Basingstoke, Hampshire RG21 6XS and

175 Fifth Avenue, New York, N.Y. 10010

Companies and representatives throughout the world

PALGRAVE MACMILLAN is the global academic imprint of the Palgrave Macmillan division of St. Martin's Press, LLC and of Palgrave Macmillan Ltd. Macmillan ${ }^{\circledR}$ is a registered trademark in the United States, United Kingdom and other countries. Palgrave is a registered trademark in the European Union and other countries.

ISBN 978-1-349-35590-7

ISBN 978-0-230-59100-4 (eBook)

DOI $10.1057 / 9780230591004$

This book is printed on paper suitable for recycling and made from fully managed and sustained forest sources. Logging, pulping and manufacturing processes are expected to conform to the environmental regulations of the country of origin.

A catalogue record for this book is available from the British Library.

Library of Congress Cataloging-in-Publication Data

Economic integration in Asia and India/edited by Masahisa

Fujita. pcm. Includes bibliographical references and index.

1. India-Foreign economic relations-Asia. 2.

Asia-Foreign economic relations-India.3. Asia-Economic integration.

I. Fujita, Masahisa. HF1590.15.A78E36 2007 337.1'5—dc22 2007017071

$\begin{array}{rrrrrrrrrr}10 & 9 & 8 & 7 & 6 & 5 & 4 & 3 & 2 & 1 \\ 17 & 16 & 15 & 14 & 13 & 12 & 11 & 10 & 09 & 08\end{array}$




\section{Contents}

List of Tables vi

List of Figures viii

Preface $\quad \mathrm{x}$

Notes on the Contributors $\quad \mathrm{xi}$

Introduction xiv

1 India, Japan and Asia 1

Jagdish Bhagwati

2 East Asia: Regional Integration among Open Economies Homi Kharas, Enrique Aldaz-Carroll and Sjamsu Rahardja

3 The Relationship between China and India within the Framework of Asian Economic Integration

Zhang Yuyan

4 Economic Cooperation between Thailand and

India and its Implications for the Asian Community

Chularat Suteethorn

5 The Position of India in the Asian Economy: Progress of Economic Integration and Poverty Alleviation

Shuji Uchikawa

6 India's Agricultural Challenges and their Implications for Growth of its Economy

Ramesh Chand

7 Conclusion and Summary

Index 


\section{List of Tables}

2.1 Growth rates and shares of exports, imports and GDP 16

2.2 Destination of exports and sources of imports 17

2.3 Decomposition of intraregional export growth, 1994-2004

2.4 Selected coefficients in generalized least-squares regressions

2.5 Countries' share in East Asia's global trade in parts and components and growth rates of their exports and imports of parts and components

2.6 Export composition by factor intensity, 1994 and $2004 \quad 27$

2.7 FDI inflows by origin 31

2.8 Sources of portfolio investment to East Asia (excluding Japan) 35

2.9 Estimates of news coefficients in domestic equity return 38

2.10 Imports to major East Asian markets, 1994 and $2004 \quad 46$

2.11 Data characteristics (equity return) 50

3.1 Exports of trade groupings 61

3.2 Recently established or proposed FTAs in Asia, 1999-2004 63

4.1 Trade volume between Thailand and India, 2000-04 92

4.2 Top-ten Thailand's export products to India, 2004

4.3 Top-ten Thailand's import products from India, $2004 \quad 93$

4.4 Economic indicators (India and Thailand), 2003 and $2004 \quad 95$

4.5 Tariff reduction and elimination for products covered
under the Early Harvest Scheme (EHS)

4.6 Trade in 82 EHS in products Jan-Oct $2005 \quad 99$

4.7 Fast track and normal track tariff reduction timeframes 101

4.8 Foreign investment in Thailand from major countries 105

4.9 India-Thailand consolidated list of items for the EHS 112

5.1 Growth rates of gross domestic product between 1981-82 and 1990-91 and between 1991-92 and 2003-04

5.2 Growth rates of gross domestic product in the manufacturing sector 
5.3 India's regional trade 126

5.4 India's balance of payments 129

5.5 Estimates of consumption of crude oil 130

5.6 Employment and unemployment 136

5.7 Employment elasticity across industries 137

5.8 Per capita NSDP and the poverty ratio 139

6.1 Growth rate in GDP agriculture and non-agriculture sectors in different periods, per cent/year 152

6.2 Growth rates (\%) in output, input and value added in agriculture since 1950-51 at 1993-94 prices 153

6.3 Level and growth in per worker farm income at 1993-94 prices

6.4 Share of agriculture in the economy's total output and employment

6.5 Per worker income in agriculture and non-agriculture sectors at 1993-94 prices 158

6.6 Extent of land degradation in India 163

6.7 Public investment in agriculture at 1993-94 prices 164

6.8 Subsidies in Indian agriculture 165

6.9 Percent of market arrival of rice and wheat procured by official agencies in various states, average of 1994-95 to 1996-97

6.10 Required growth rate in non-agricultural sector to achieve $8 \%$ and $10 \%$ growth rate in economy corresponding to various growth scenarios in agriculture sector 


\section{List of Figures}

2.1 Percentage point change in intraregional and extraregional market shares between 1994-96 average and 2002-04 average

2.2 World transportation costs as measured by CIF/FOB ratios, 1970-98

2.3 Share of foreign affiliates (FA) in total China's trade, 1992-2004

2.4 Processing trade of foreign affiliate firms in China by partner country, 2002

2.5 Production networks in East Asia: new vs. traditional 30

2.6 China's foreign direct investment cases, 2002-04 32

2.7 Return correlations: country versus region (excluding Japan)

2.8 Return correlations: country versus Japan 36

2.9 Return volatility explained by regional, Japan, and US news

2.10 Manufacturing and services productivity in China and India

2.11 India's revealed comparative advantage 42

3.1 Trade-development between China and India, 1998-2004 71

3.2 India's and China's exports in proportion to the other's imports

4.1 Monthly wages of industry workers (US\$), $2003 \quad 109$

4.2 Office rent monthly per square metre (US\$), $2003 \quad 109$

4.3 Housing rent for expatriates (US\$ per month), $2003 \quad 110$

4.4 Electricity rate for business use (US\$) per month, $2003 \quad 110$

4.5 Calculation example of selected annual cost (US\$), $2003 \quad 111$

4.6 Cost structure index, $2003($ Bangkok $=100)$

5.1 Gross fixed capital formation at 1993-94 prices 120

5.2 Industry-wise growth rates 123

5.3 Production and imports of crude oil 131

5.4 Population below the poverty line and its share in total population 
6.1 Annual growth-rate in GDP agriculture based on 5-yearly moving average series: 1956-2004 152

6.2 Growth rate in GDP agriculture and non-agriculture 157

6.3 Regional variations in crop output per hectare of cultivated area during 2002-03 159

6.4 Input subsidies as \% of GDP agriculture 164

6.5 Public investments in agriculture as \% of GDP agriculture 


\section{Preface}

This book is an outcome of the international symposium on 'Economic Integration in Asia and India', held at the Keidanren Hall in Tokyo, 8 December 2005. The symposium was organized by the Institute of Developing Economies at the Japan External Trade Organization (JETRO), Asahi Shimbun and the World Bank. The symposium specifically focused on how Asian countries would be affected by India's participation in economic integration, how India itself would be affected domestically in this process, and, finally, how the regions could successfully pave the way towards economic integration.

Chapter 1 presents a keynote lecture on Indian growth given by Professor Jagdish Bhagwati of Columbia University. In Chapter 2 economic integration in East Asia is discussed by Homi Kharas, in cooperation with Enrique Aldaz-Carroll and Sjamsu Rahardja of the World Bank. In Chapters 3 to 5 the relationship between India and each country from the perspectives of China, Thailand and Japan respectively is discussed by Zhang Yuyan, Chularat Suteethorn and Shuji Uchikawa. In Chapter 6 the problems of India's agriculture are discussed by Ramesh Chand, while Chapter 7 presents a summary of the panel discussion session.

The editor would like to thank Asahi Shimbun and the World Bank for their enthusiastic support as cosponsors of the symposium, as well as the keynote speaker and panel discussants for making this highly successful symposium possible, and for agreeing to contribute papers for this volume.

MASAHISA FUJITA 


\section{Notes on the Contributors}

Enrique Aldaz-Carroll is a World Bank economist presently based in Indonesia, and has written papers on export competitiveness, regional trade integration, technological upgrading of exports, product standards and poverty. He has worked as a consultant for, among others, the United Nations. He holds a Master in Economics (London School of Economics and Political Science and a PhD in Economics (Institute of Development Studies, Sussex University).

Jagdish Bhagwati is University Professor, Economics and Law, at Columbia University and Senior Fellow in International Economics at the Council on Foreign Relations. He was Economic Policy Adviser to the Director General of GATT and also served as Special Adviser to the UN on Globalization and External Adviser to the Director General, WTO. Currently, he is a member of UN Secretary General Kofi Annan's Advisory Group on the NEPAD process in Africa. Five volumes of his scientific writings and two of his public policy essays have been published by MIT Press. The recipient of six festschrifts in his honour, he has also received several prizes and honorary degrees. Professor Bhagwati's latest book In Defense of Globalization was published by Oxford University Press in 2004 to worldwide acclaim.

Ramesh Chand is ICAR National Professor at the National Centre for Agricultural Economics and Policy Research, New Delhi, India. He was Visiting Professor at the University of Wollongong, New South Wales, Australia (2000); and Visiting Fellow at the Institute of Developing Economies, Chiba, Japan (2003). Dr Chand has published six books and 60 research papers on themes related to agricultural growth and development, food policy and international trade.

Masahisa Fujita is President of the Research Institute of Economy, Trade and Industry, Japan, Professor of Konan University and Adjunct Professor of the Institute of Economic Research, Kyoto University. He gained his PhD from the University of Pennsylvania in 1972 and has 
taught at the University of Pennsylvania and Kyoto University. He was President of the Institute of Developing Economies, JETRO, from October 2003 to April 2007.

Homi Kharas is currently a Visiting Fellow at the Wolfensohn Center for Development at the Brookings Institution in Washington, DC. He was the Chief Economist of the East Asia and Pacific Region of the World Bank and Director of the region's Poverty Reduction and Economic Management Department from 1999-2007 and has been following East Asian economies since 1982. He joined the World Bank in 1980 and has worked in the Research Department, the Latin America and Caribbean region, and the Economic Policy Department. From 1990 to 1991, he worked as a Senior Partner with Jeffrey D. Sachs and Associates, advising countries in East/Central Europe and the Soviet Union on transition issues. He completed his PhD in economics at Harvard University and his undergraduate studies at the University of Cambridge. He has published widely in the areas of external debt and developing countries' foreign borrowing and fiscal risks and contingent liabilities.

Sjamsu Rahardja is an economist for the World Bank Office in Jakarta, Indonesia, and was a visiting fellow at the Peterson Institute for International Economics. His research areas include subsidies and insurance offerings by firms, corporate regulation and financing constraints, and the effect of international firm's productivity. He received his $\mathrm{PhD}$ in economics from Georgetown University.

Chularat Suteethorn, a Thai national, presently serves as Deputy Director-General of the Fiscal Policy Office, Ministry of Finance, Thailand. Previously, she served as Bureau Director of the Bureau of International and Macroeconomic Policy. She gained her Bachelor's Degree in Economics from Kasetsart University, Bangkok and a Master of Development Studies on Economic Policy and Planning from the Institute of Social Studies, the Netherlands. She joined the Ministry of Finance as an Economist in 1977. She was nominated by the Minster of Finance of Thailand to work as Economic Officer at the ASEAN Secretariat in Jakarta during 1983-88. She serves as a resource person on economic cooperation under the ASEAN Committee on Finance and Banking, with experience at the ASEAN Free Trade Area. 
Shuji Uchikawa is Senior Researcher, Bangkok Research Center, JETRO. He gained his PhD from Jawaharlal Nehru University in 1994, and has taught as a Lecturer in the Faculty of Administration and Informatics, Tokoha-gakuen Hamamatsu University in 1993-96 and was a Visiting Faculty Member of the Indira Gandhi Institute of Development Research, Mumbai in 2000-02.

Zhang Yuyan is Deputy Director of the Institute of Asia-Pacific Studies, Chinese Academy of Social Sciences (CASS), China. His research area is in institutional economics and international political economy. He gained his PhD in economics from the Graduate School of CASS in 1991. He has published widely in the areas of institutional economics, international political economy, and China's economic security. 


\title{
Introduction
}

\author{
Masahisa Fujita
}

In the march of globalization in the world economy, the regional economic integrations which have been progressing institutionally in the EU and the Americas are now substantially under way among countries in Asia, including Japan, Korea, China and the ASEAN countries too. India, often compared to a Gigantic Elephant, has also taken steps on its passage towards economic integration. By substantially raising its trade and investments in the Asian markets, this Elephant may walk faster than ever and come to play an important role in the progress of Asia's economic integration. India's full-scale participation in the Asian market will affect other East Asian countries, which in turn will also have manifold influences on India.

India initiated economic reforms in 1991 and gave up the import substitution strategy which she had followed since independence. This was the turning point from which India started to adjust her economy to globalization; previously the Indian market had been distorted by regulations and was dormant. The purpose of the economic reforms was to activate the market through competition, and india tried to introduce advanced technology from developed countries through foreign direct investment and increase her exports.

After the industrial licensing regulation, which had limited investment in the manufacturing sector, had been swept away, there was a boom in investment in the manufacturing sector, particularly in consumer durable goods industries. The investment promoted growth of production, and the manufacturing sector maintained growth rates of gross value-added around 10 per cent. However, after reaching a peak in 1996, investment declined.

In sharp contrast with the manufacturing sector, investment in the service sector has risen since the end of the 1990s and the sector has grown rapidly. Primary, secondary and tertiary industries accounted for 34 per cent, 24 per cent and 42 per cent of GDP respectively in 1991; and 21 per cent, 27 per cent, and 52 per cent respectively in 2004, during which period the principal industry shifted from agriculture 
to service. On the other hand, industrial structure of the workforce presents a different picture. The primary, secondary and tertiary industries accounted for 62 per cent, 15 per cent, and 23 per cent respectively of the total labour force in 1999, which means that agriculture account for a large proportion of the underemployed workforce, which cannot get sufficient income to survive. Agriculture is still very important in India.

India has actively approached ASEAN in the twenty-first century; for example the Indo-ASEAN summit has been held back-to-back with the annual ASEAN Summit since 2002, and the first East Asia Summit took place in December 2005. The Government of India will maintain its 'Look East Policy'. One reason why India is approaching ASEAN is to attract foreign direct investment from developed countries. The domestic market is not large in spite of a population of one billion, and the investment boom of the mid-1990s was over after utilization of capacity decreased and over-investment emerged. Domestic demand did not increase as much as expected. Exports therefore become important as an outlet, but India does not have neighbouring countries with big domestic markets. If India's economic integration with ASEAN progresses, foreign direct investment may flow into India to capture not only the domestic market but also the ASEAN market.

At the same time, economic integration might have a reverse effect. As economic integration makes exporting from ASEAN to India easier, some foreign companies may withdraw from India. In fact, a Japanese company closed down its unit in India and its units in Thailand started to export to India. Indian companies must improve international competitiveness vis-à-vis foreign companies to grow further under globalization. The industrial world is keen to take advantage of the business opportunities created by economic integration with NorthEast Asia and ASEAN. Although the Indian media argued against the inflow of Chinese goods around 2000, calling it a threat, our main contention is that foreign trade with China is an expansion of business opportunities.

The Institute of Developing Economies (IDE-JETRO), Asahi Shimbun and the World Bank organized an international symposium entitled 'Economic Integration in Asia and India' in Tokyo on 8 December 2005. This symposium specifically focused on how Asian countries would be affected by India's participation in economic integration, 
how India itself would be affected domestically in this process, and, finally, explored the ways in which the region could successfully pave the way towards economic integration. This book has grown out of the proceedings of the symposium.

Jagdish Bhagwati points out that the East Asian economy has developed taking advantage of foreign trade, but unless multilateralism is guaranteed it cannot maintain its growth on the basis of foreign trade. He expects East Asian countries to assert that non-trade issues such as labour standards, environment rules and capital flow control should be discussed at the Doha Round of the WTO. Homi Kharas argues that as high productivity sectors are different in East Asia, East Asian countries compensate for their weak sectors by economic cooperation. Zhang Yuyan contends that although foreign trade between China and India is beneficial for both countries, domestic interest groups are obstacles to the development of foreign trade between them. Chularat Suteethorn points out the possibility of economic cooperation between Thailand and India, while Shuji Uchikawa finds that, though India is benefiting from globalization, poverty in some unirrigated areas creates trade conflict on palm oil imports from Malaysia and Indonesia. Ramesh Chand discusses the bottleneck of agricultural growth in India.

In the dynamic economic integration process under way in East Asia, there are various interesting aspects worthy of study. We hope that this book touches on some of them and will be happy if it contributes to further understanding some of the issues involved. 